\title{
Archigenes and the syndrome of vertigo, tinnitus, hearing loss, and headache
}

\author{
Alex E. Wright ${ }^{1} \cdot$ Joseph McFarland ${ }^{1} \cdot$ Mohammadali M. Shoja ${ }^{2,3}$ (D) \\ Received: 18 July 2019 / Accepted: 5 August 2019 / Published online: 12 August 2019 \\ (C) Springer-Verlag GmbH Germany, part of Springer Nature 2019
}

"Fly then and bid Archigenes prepare - An antidote, if life be worth your care."

Juvenal, Rome, $1^{\text {st }}$ Century A.D.

\section{The life and works of Archigenes}

Archigenes (or Arkhigenes, Greek: A $\rho \chi \curlyvee \varepsilon$ ć $\eta \varsigma$ ), the son of Philippus, was born in Apamea of Syria [1]. The circumstances of his childhood and early education are unknown to us, but we know that he moved to Rome sometime between the first and second centuries AD, contemporary with the Roman poet, Juvenal [2,3]. He studied under Agathinus, the founder of the Eclectic school, whom he later treated for a severe delirium [1]. Eclectic, literally meaning selecting or choosing, was an epithet given to individuals who refrained from attaching themselves to any particular sect, but instead selected from the ideas and principles of other sects and of diverse range of sources whichever seemed to be more plausible, legitimate, and solid [4]. Archigenes was a teacher and an innovative medical writer and practiced surgery during Trajan's reign in Rome concurrent with the largest expansion of the Roman Empire [5]. Much of his reputation is indebted to Juvenal who spoke of him as a great hero, portraying him "going about visiting his patients attended by fifty pupils, each feeling every patient's pulse by turns" [6,7].

Mohammadali M. Shoja

shoja.m@gmail.com

1 School of Medicine, University of Texas Medical Branch, Galveston, TX, USA

2 Tuberculosis and Lung Disease Research Center, Tabriz University of Medical Sciences, Tabriz, Iran

3 Seattle Science Foundation, Seattle, WA, USA
Archigenes departed from his contemporary medical views in several ways. He favored the pneumatism (as opposed to "one-and-only" humoralism), asserting that vital air (pneuma or spirit) alongside the corporeal elements, solids, and humors are implicated in the pathogenesis of ailments $[5,8]$. Maintaining that pneuma, necessary for life, enters the lung to remove the heat of the heart during diastole $[5,9]$, he proclaimed that the diseases result from an altered mixture of humors and pneuma dispersed throughout the body via nerves and vessels [10]. While believing the heart was the seat of memory and mentation, he treated mental affections by addressing the head rather than the heart [11, 12]. Galen's disapproval of this is evident in his statement, "But oh, most illustrious Archigenes! You are surely not right in addressing yourself to the head, if, in these cases, it is the heart that is affected" [11].

The history has criticized Archigenes for inventing new and obscure medical terms and for holding the opinion that typical symptomatology sometimes can be present in an atypical illness $[1,9,13]$. He has also been abundantly praised for his diligent work across many fields. His meticulous notes on limb amputations and breast lumpectomies still stand unique $[14,15]$. His surgical practice was essentially focused on patient survival and reduction of pain, noting the importance of avoiding nerves and tendons during cauterization of vessels $[14,16]$. He is known for describing several characteristics of the arterial pulse pattern broadly similar to the modern-day principles of pulse palpation [6, 17]. Even though much of his works was eclipsed by Galen's, his pulse pattern methods were lauded by Galen himself [17].

Archigenes wrote at least 11 treatises of which only a few dispersed fragments have survived through the writings of Galen (Fig. 1), Aëtius, Aretaeus, and later physicians [2, 3, $5,6,18]$; these were staple in medical education well into the middle ages [19]. His observations on pelvic cellulitis and abscess have reached us through the writings of Aëtius [6] and his theories on poisons and toxicology by Alexander of Tralles $[9,20]$. When Rhazes, a renowned Persian physician, 
Fig. 1 Early portraits of Greek medical celebrities from a manuscript of Dioscorides, circa $500 \mathrm{AD}$ (image courtesy of Wellcome Library, London)

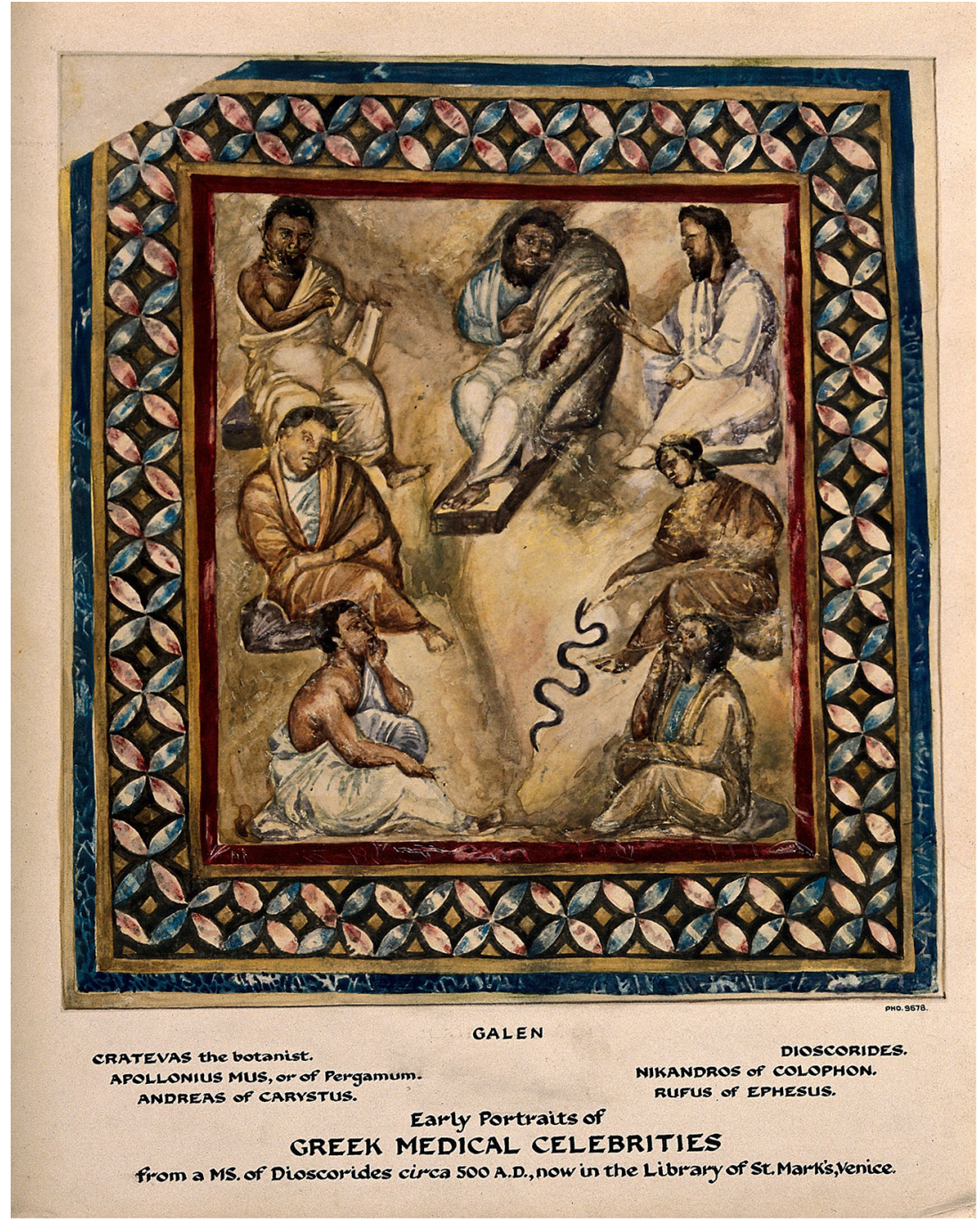

compiled his masterpiece Kìtāb al-Hīwwì (The Continens) in the tenth century aimed at gathering the original and first-hand clinical communications of his predecessors, the authority of Archigenes was pronounced on numerous passages.

In this article, we explore a syndrome of paroxysmal vertigo, tinnitus, headache, and hearing loss as described by Archigenes and transmitted to us through the writings of Galen and Rhazes. We then show how this notion and those of other ancient physicians hallmarked a progress toward the portrayal of what was later known as Ménière disease. A brief history of the vestibulocochlear symptoms in the ancient and medieval literature is presented at the end.

\section{Archigenes in De Locis Affectis of Galen and Continens of Rhazes}

Rudolph Siegel, in his landmark work Galen On Sense Perception, provided a translation of an excerpt from
Galen's De Locis Affectis (On the Diseased Organs) on skotoma:

All these affections start obviously in the head and especially the affection which is called skotoma, the name of which indicates its nature. People who are subject to this ailment are affected by skotoma of their vision on account of the smallest causes, so that they often fall, especially when they turn around...

Archigenes described likewise these facts in his first book, The Pathognomonic Signs of Chronic Diseases, when he spoke of a spell of vertigo (skotoma) in the following terms: 'This affection has two causes, either in the head or in the hypochondria.' Then, he attempted to distinguish the two kinds by saying that vertigo representing a primary affection of the head is preceded by ringing of the ears, pain and heaviness in the head, or a disturbance of the sense of smell and damage of the sensory parts originating there... He further stated that, when vertigo originates in the cavity of the stomach, it is 
preceded by pain in the cardia and nausea. As I myself have stated previously more than once, we have to realize that, even if the head suffers by sympathetic affection related to another organ, it is still the head to which we have to attribute the symptoms as they appear. (quoted from Siegel 1970, pp. 138-139) [21]

Although the original writings of Archigenes have been lost, dispersed excerpts in Galen and other ancient or medieval figures have provided us with indirect evidence for his theories and practice. One of these medieval figures was Abū Bakr Muhammad ibn Zakariyyā al-Rāzī, also known as Rhazes in Latin (Fig. 2), a Persian physician and philosopher at ninth to tenth century AD [22]. He traveled to Africa, Spain, and Jerusalem studying and practicing medicine and was appointed the chief of the Royal Hospital in Ray and
Muqtadari Hospital in Baghdad [23]. He is known as one of the most original physician-philosophers among Arabspeaking peoples [24]. After his death, more than 50,000 pages from his personal records and writings were retained. The largest of his works, The Continens, is an anthology of previous Greek, Indian, and Arabian medical authorities [25], to which Rhazes added his own views and occasionally original, brief clinical cases to highlight the efficacy or inefficacy of a given therapy [23]. In his Continens, Rhazes quoted Archigenes:

...if the origin of the vertigo is from an affection of the head, the vertigo is preceded by tinnitus, headache, sensory heaviness and sensory weakness [including sensory disturbances such as hearing loss]. But if vertigo arises from a cause in the stomach inlet [cardia], it is
Fig. 2 Rhazes in his laboratory at Baghdad; an oil painting of by Ernest Board (image courtesy of Wellcome Library, London)

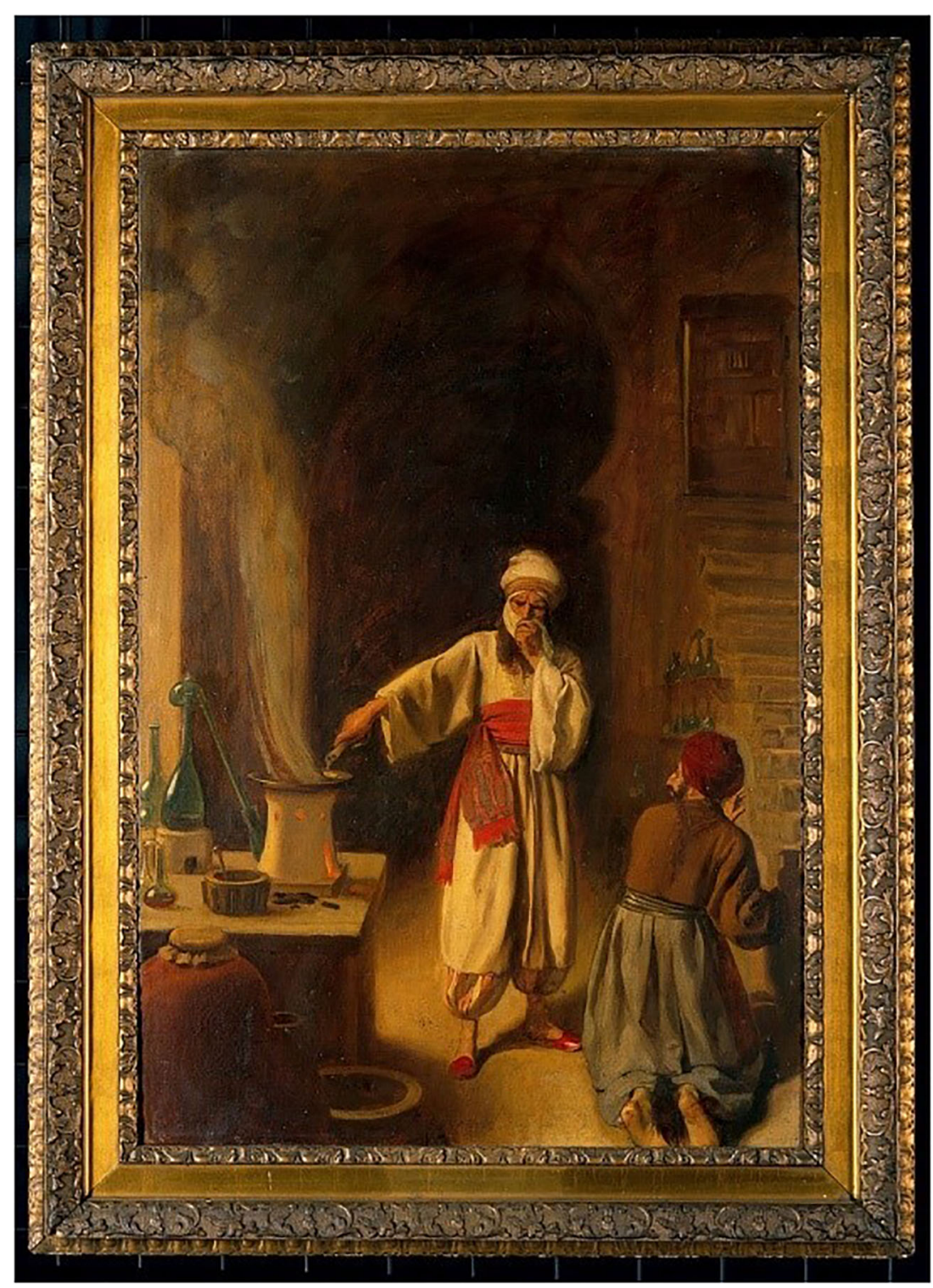


accompanied by severe palpitation and nausea. (Translated from Bateni) [26]

Although it is difficult to put modern disease names to an old symptomatic description, Siegel maintains that Archigenes' description of vertigo adequately represents Ménière disease. He further points out that Galen's attribution of the cause of ailment to a disturbance of the blood flow in the arteries of the ear and skull base testifies to his correct localization of this syndrome [21]. A careful revisiting the text of Galen reveals that Archigenes did actually mention two clinical forms of the paroxysmal vertigo of cephalic origin: one being preceded by tinnitus and headache and the other by an olfactory disturbance and other sensory changes (possibly corresponding to a vestibular migraine). Rhazes has a slightly different interpretation of Archigenes where he surmises, after citing Archigenes, if the brain or head is the origin of vertigo, the patient "invariably suffers from heaviness in the ears and visual blurring," and "experiences a severe pain [headache] and tinnitus beforehand; his senses of audition and olfaction are impaired and sometimes a weakness in vision manifests alongside" (Bateni, 2019). Rhazes is more explicit in his account of hearing loss in the cepalic vertigo of Archigenes.

In understanding the evolution of clinical science, it is important to note that this evolution occurred through the centuries of transmission and adoption of knowledge by the ancient and medieval authorities, that the modern classification of diseases is a culmination of the collective efforts of our predecessors, and that in the ancient and medieval literature, the diseases with overlapping cardinal symptoms were often grouped together under a common entity. To more precisely illustrate this, one could refer to the aforesaid example; if Ménière disease and vestibular migraine were to be discerned as the same and singular entity, then we would characterize such an ailment with paroxysms of vertigo and headache, sometimes associated with tinnitus and hearing loss and sometimes with visual and olfactory disturbances. Notwithstanding the broad range of its inciting events and pathologies known today, associating vertigo, tinnitus, hearing loss, and headache as a categorical entity was a step forward in diagnosis making by distinguishing vertigo syndromes from vertigo as a symptom and thus laid the foundation for future delineation of a new class of the otological and neurological disorders.

\section{Vestibulocochlear symptoms in the ancient and medieval medicine}

In the fifth century $\mathrm{BC}$, Hippocrates described vertigo and otitis as "the presage of disaster" [27]. The Corpus Hippocraticum describes tinnitus in association with pulsating headache and hearing loss: “...small vessels overfill with blood... the vessels raised up and throb, pain occupies the entire head, the ears ring and the patient hears nothing. The ears ring because the vessels are throbbing and quivering, for then there is a ringing in the head... The patient cannot tolerate wind or sun; his ears ring, he is vexed by any noise, and he vomits saliva and scum, sometimes food as well..." [28]. Further upon the same subject, Hippocrates gives us a mechanistic explanation for these symptoms: the brain occupies the empty space near the ear; thereby, a throbbing vessel would affect the juxta-auricular air space, resulting in the perceived sound [28]. Though some scholars such as Maltby regards Hippocrates' description as a progression toward what nowadays is recognized as Meniere syndrome, a mention of vertigo is characteristically lacking in this passage. The combination of pulsating headache, tinnitus, hearing loss, and hypersensitivity to sounds most likely represents an atypical migraine, or more precisely the cochlear migraine reported by Lai and Liu (2018).

Medical procurements were of social relevance in times of antiquity (Fig. 3 and Cover). The deaf was often viewed with resentment and as unintellectual even to the extent of denouncing certain rights [29]. History has recorded that Julius Caesar (101-44 BC; Fig. 4) was afflicted with an episodic falling sickness, frequent headaches and dizziness. Many among ancient physicians and later historian-physicians have related these symptoms to epilepsy. Cawthorne, after examining the historical records in the light of modern medical knowledge, expressly said that the time of the onset of Caesar's falling attacks and the fact that his illness did not deteriorate his mental or physical capacity over time, it was much more likely to have been a benign disorder such as Ménière disease [30]. Emperor Claudius (10 BC-54 AD) himself suffered from a chronic hearing loss. History recalls that eventually, the rights of an average citizen were restored for the deaf during Justinian's reign in the sixth century [29].

The mention of tinnitus is found in the ancient writings of Mesopotamia, China, India, and Greece. De Medicina of Celsus (25 BC-50 AD), an authoritative source among the medical sects for at least seven centuries, is often cited as one of the first to give a clinical classification of tinnitus [28,31]. Celsus associated tinnitus with three separate clinical etiologies: common cold, prolonged headache, and the onset of a serious disease, e.g., epilepsy [28]. Although De Medicina scarcely touches on the subject of vertigo, it is alluded that Celsus had his patients undergo treatments with concoctions of rose or laurel leaves along with dietary and lifestyle modifications for what is now believed to be vestibular migraine [31].

Juvenal (born circa 55 AD) spoke of alcohol-induced vertigo in his poetry, "the roof spins around dizzy, the table dances, and every light is double". The second century Alexandria-trained physician, Aretaeus, referred to skotoma and vertigo as being synonymous and delineated tinnitus as being either primary, secondary to headache or as an indicator of mania or epilepsy [32]. He did not, 
Fig. 3 and Cover A fresco from House of Sirico in ancient Pompeii, demonstrating the physician Japyx healing the soldier Aeneas, currently on display at the Museo Archeologico Nazionale in Naples (image courtesy of JoJan)

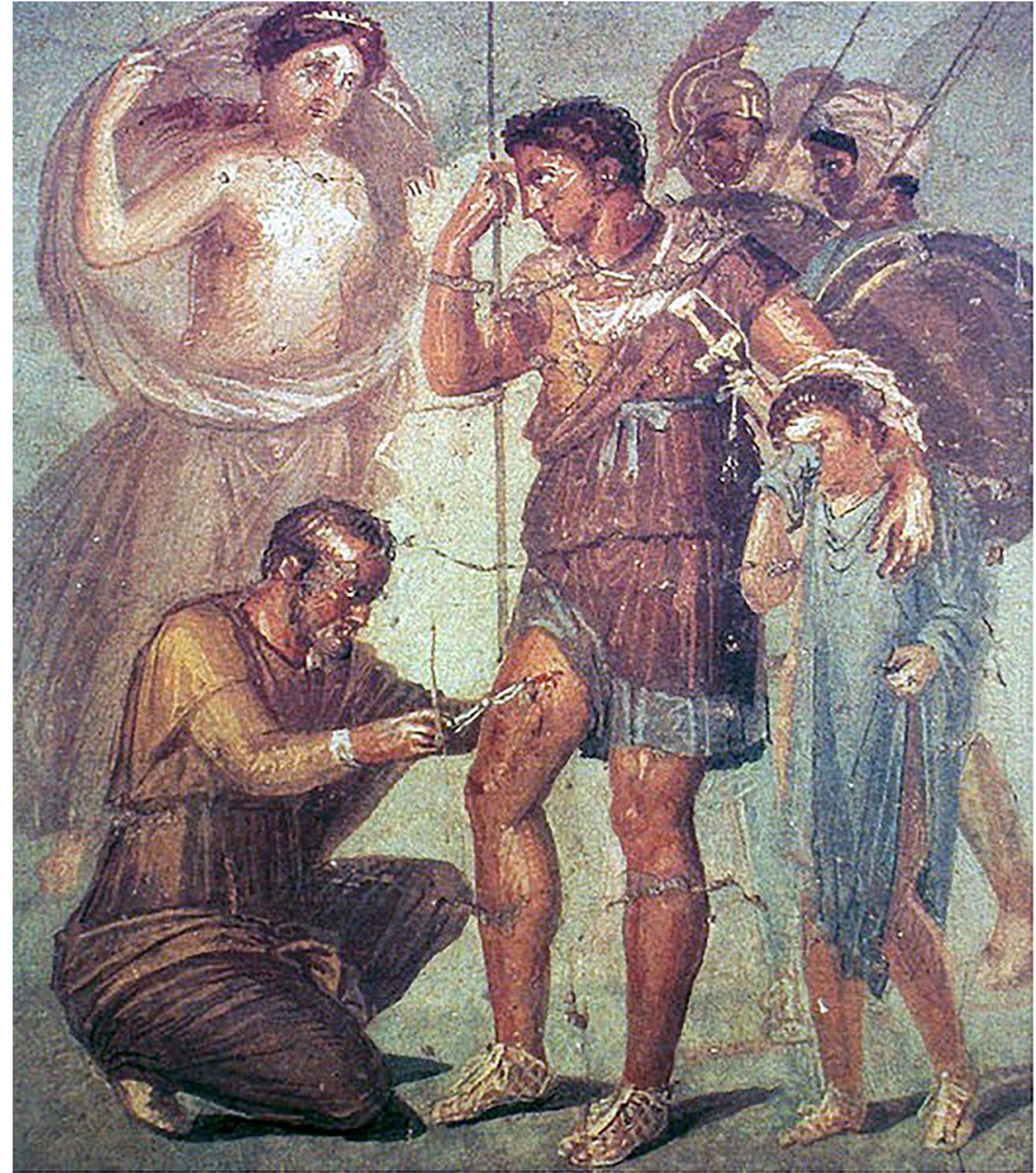

however, relate these symptoms to an affection of the inner ear, and differs from Archigenes in that he did not describe tinnitus and vertigo together in a single disorder [33]. Galen extensively elaborated upon skotoma, a clinical symptom denoting dizziness and dimness of vision. He further differentiated between dizziness and true vertigo, but still regarded the latter as being a form of skotoma.

Aëtius of Amida (502-575 AD) who drew most of his materials from Posidonius (135-51 BC) and Archigenes treats of vertigo in much the same way as the latter two did [34,35]. Alexander Tralles, a Lydian physician of the sixth century, described vertigo in association with a feeling of heaviness in the head (possibly headache) and diminished sight and sensibility as a form of "epilepsy," a common term during the antiquity that used to indicate a state of lost consciousness, sensations and perceptions where the patient was "no different from the dead" [36]. Paulus of Aegineta, the seventh century Byzantine physician, recounted vertigo and its treatment, described primary vertigo as being associated with "noises in the ears" and distinguished between the primary vertigo originating from the head from a secondary vertigo arising from the stomach, which bears a close resemblance to the classification of Archigenes [37].

In the tenth century, the Persian physician and polymath Avicenna gave the most comprehensive account of vertigo ever written, which retained its significance until the sixteenth century when the humoralism gradually declined and was put aside by European scholars. He attributed vertigo to a multitude of unnatural causes including morbid vaporous matter generated in the brain or produced elsewhere such as in the stomach and then ascended and accumulated in the brain. Morbid humors likewise, especially the atrabilious or phlegmatic humors arising from the liver, heart, uterus, or any other organ as well as unbalanced constitution and head trauma, could all cause vertigo. Each of these, as Avicenna described, had its own symptoms and specific treatment. His chapter on tinnitus is shorter but more or less in the same manner of clinical argument. It is notable that Avicenna scarce any associated the vestibulocochlear symptoms together other than in a case of tinnitus and hearing loss. This is justifiable for his anatomy evidently localized the latter two to the ears but vertigo to the substance or ventricles of the brain. 
Fig. 4 Birth of Julius Caesar by Cesarean operation. François Rousset performed a laparotomy with hysterotomy in the sixteenth century and named this operation after Caesar who was born this way. It has been said that Caesar suffered from Ménière attacks. (image courtesy of Wellcome Library, London)

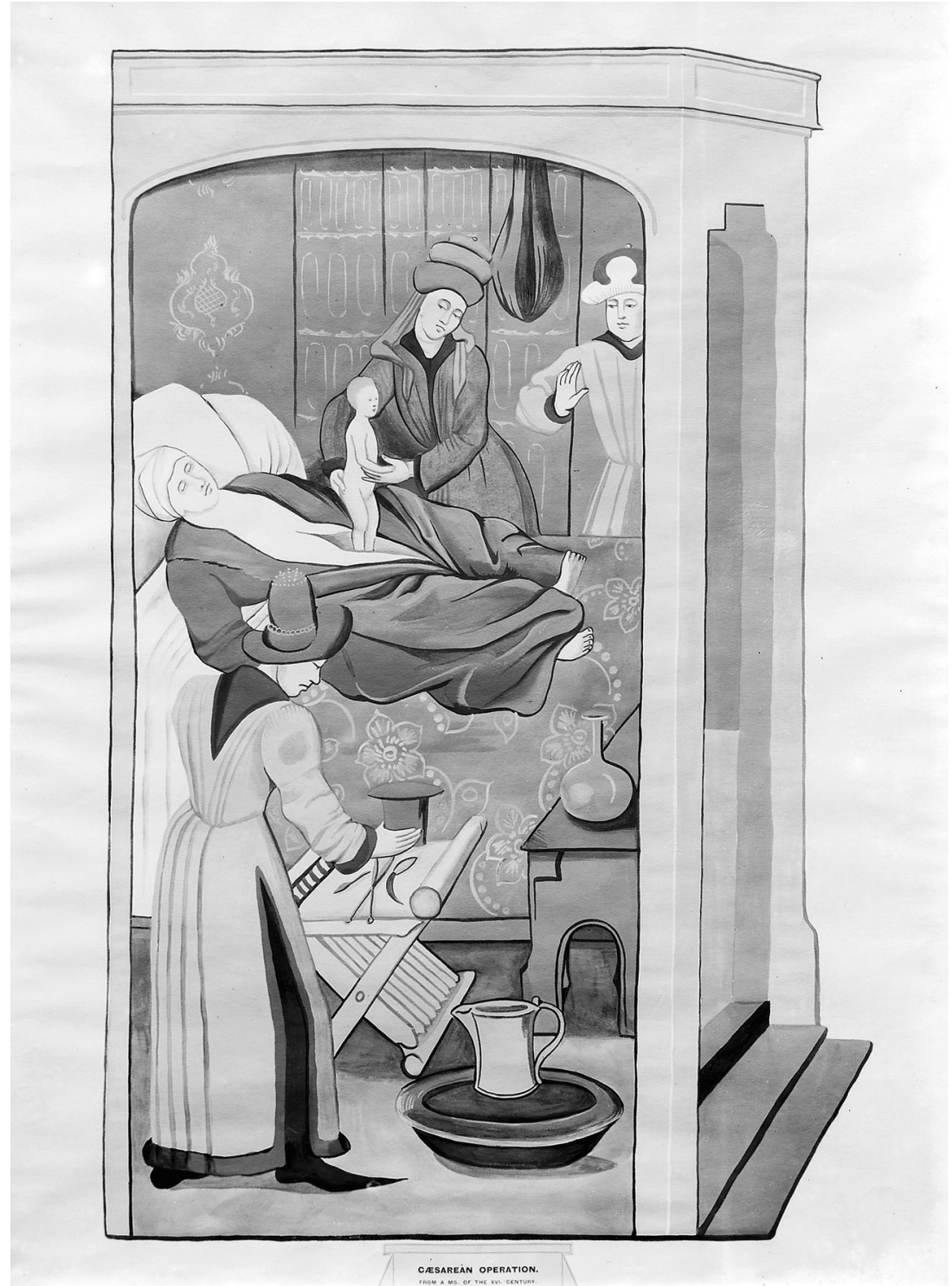

After exposition of the clinical syndrome of paroxysmal vertigo, tinnitus, headache and hearing loss by Archigenes, similar descriptions appeared in literature such as in the 1565 book of Angeli Bonaventura (De Vertigine et Scotomia) and in the early 1700 s writing of Jonathan Swift, both of whom were believed to have suffered from the disease themselves [38, 39]. Whether or not these later observations rooted in or were influenced by Archigenes is hard to claim and we do not intend to speculate upon it for the sake of this undertaking. So, it was ultimately the Frenchman Prosper Ménière (1799-1862, Fig. 5) who first reported, in great details, a series of patients with this constellation of vestibulocochlear symptoms. One of his first patients was a young woman with acute onset of vertigo, sudden deafness, and a semicircular canal abnormality who died five days later [40].

Ménière subsequently collected his observations of the similar condition and conducted postmortem studies during his appointment as the chief physician at the Institut des Sourds-Muets of Paris [41]. In 1861, he presented a paper before the Académie de Médecine de Paris where he spoke of episodic vertigo lasting hours, associated with unilateral tinnitus, deafness and ear fullness [42]. His theory that all these symptoms were from a single dysfunction in the semicircular canals led to the disease being aptly named after him. In 1895, the Viennese otologist, Josef Gruber (1827-1900), observed a great variation of the endolymphatic sac in a study of more than 100 temporal bones and postulated that when the sac is exceptionally small, the outflow of endolymph might be impeded and the abnormal tension raised might result in the onset of Ménière attacks [43-45]. The endolymphatic hydrops in the inner ear was later noticed by Richard Clark via postmortem examinations, which demonstrated the ballooning of the Reissner membrane into the perilymphatic space of the inner ear in this condition [46]. 
Fig. 5 Painting of Prosper Ménière by G. Bodinier. (image courtesy of Wellcome Library, London)

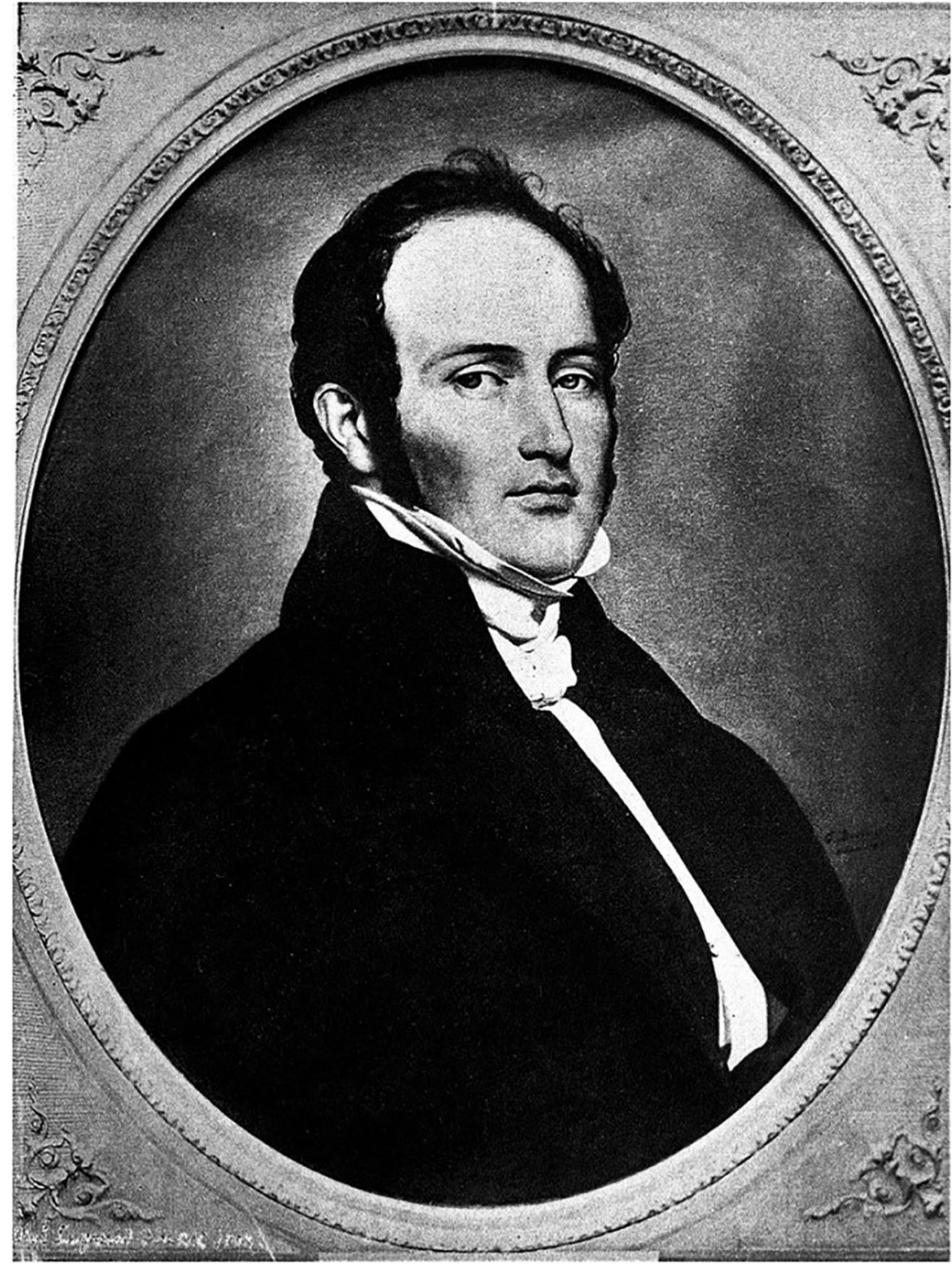

\section{Epilogue}

The individual vestibulocochlear symptoms were well recognized by the ancient Greeks and Romans [47]. Archigenes' description of a clinical syndrome of paroxysmal vertigo, tinnitus, headache, and hearing loss has reached us through the writings of Galen and Rhazes. The uniqueness of this contribution lies in his grouping of these symptoms and depiction of a clinical tetrad — or a syndrome - which is presumably the earliest found description of Ménière disease. Archigenes distinguished two types of vertigo. Although it is hard to attribute either type to the present-day classification (central versus peripheral vertigo), a vertigo associated with tinnitus most likely represented a peripheral pathology in the vestibulocochlear nerve or inner ear. Archigenes' detailed and avid search for medical knowledge has contributed to the foundation of modern medicine. Less than a handful of previous sources have alluded to Archigenes as the first who described a constellation of the vestibulocochlear symptoms similar to Ménière's [21, 48]. Even though Archigenes himself was in no position to discover the true seat and cause of the condition, his scientific assimilation of the vestibulocochlear symptoms deserves credit in the history of medicine. It is important to bring into light the works of physicians of antiquity and their clinical thoughts and discoveries as it was their works that inspired and eventually amplified medicine.

Acknowledgments The authors are grateful to Dr. J.M.S. Pearce, Hull Royal Infirmary at UK, for reviewing the preliminary drafts and his suggestions to this text.

\section{Compliance with ethical standards}

Conflict of interest On behalf of all authors, the corresponding author states that there is no conflict of interest. 


\section{References}

1. Smith W (1850) Dictionary of Greek and Roman biography and mythology, 63rd edn. Taylor and Walton, Boston, p 268

2. Singer C (1921) Medicine. In: Livingstone R (ed) The legacy of Greece. Clarendon Press, Oxford, pp 201-248

3. Singer C (1956) Galen on anatomical procedures. Oxford University Press, London, $\mathrm{p} \mathrm{XV}$

4. Webster N (1828) A dictionary of the English language, 1st edn. Barker, New York

5. McCallum JE (2008) Military medicine: from ancient times to the 21st century. ABC-CLIO, 25-26

6. Simpson J (1859) Clinical lectures on the diseases of women. Med Times Gaz 19(25-28):103-107

7. Gifford W (1817) The satires of Decimus Junius Juvenalis and of Aulus Persius Flaccus. Oxford University, London, p 172

8. Forbes J, Tweedie A, Conolly J, Dunglison R (1845) The cyclopaedia of practical medicine: comprising treatises on the nature and treatment of diseases, Materia Medica and therapeutics, medical jurisprudence, Etc., Etc. In: Vol 3. Lea and Blanchard, Philadelphia, pp 194-195

9. Allbutt TC (1910) The FitzPatrick lectures on Greek medicine in Rome: delivered at the Royal College of Physicians of London. Br Med J 2:1481-1489

10. Prioreschi P (1996) A history of medicine: Roman medicine. Horatius Press, Omaha, pp 171-173

11. Johnson J, Johnson H (1842) Some of most important discoveries of Galen (a letter appeared in periscope or circumspective review). Medico-chirurgical Rev 36:524-527

12. Villanova A de, Feliu E, Ferre L, et al (1975) Arnaldi de Villanova Opera medica omnia. In: McVaugh M (ed) Vol 1. Tractatus de intentione medicorum, Barcelona, $\mathrm{p} 154$

13. Roby C (2015) Galen on the patient's role in pain diagnosis: sensation, consensus, and metaphore. In: Petridou G, Thumiger C (eds) Homo Patiens - approaches to the patient in the ancient world, 5th edn. Brill, Boston, pp 318-319

14. Stannard J (2008) Archigenes. In: Gillispie C (ed) Complete dictionary of scientific biography, 1st edn. Charles Scribner's Sons, New York, pp 212-213

15. Montalbano MJ, Sharma A, Oskouian RJ, Loukas M, Tubbs RS (2017) The ancient Syrian physician Archigenes and his contributions to neurology and neuroanatomy. Childs Nerv Syst 33:14191420

16. Papavramidou N, Papavramidis T, Demetriou T (2010) Ancient Greek and Greco-Roman methods in modern surgical treatment of cancer. Ann Surg Oncol 17:665-667

17. von Staden H, Chalcedonius H (1989) Herophilus: the art of medicine in early Alexandria: edition, translation and essays. Cambridge University Press 65, 284-287

18. Watson J (1856) The medical profession in ancient times: an anniversary discourse delivered before the New York Academy of Medicine, November 7, 1855. 127-128

19. Touwaide A (2008) Arkhigenes of Apameia ( 95 - 115 CE). In: Keyser P, Irby-Massie G (eds) Encyclopedia of ancient natural scientist: the Greek tradition and its many heirs. Routledge, London, pp 160-161

20. Bouras-Vallianatos P (2016) Modelled on Archigenes "theiotatos": Alexander of Tralles and his use of natural remedies ('physika'). Mnemosyne 69:382-396

21. Siegel RE (1970) Galen on sense perception. His doctrines, observations and experiments on vision, hearing, smell, touch and pain, and their historical sources 138-139
22. Shoja M, Tubbs R (2007) The history of anatomy in Persia. J Anat 210:359-378

23. Shoja M, Agutter P, Tubbs R (2015) Rhazes doubting Galen : ancient and medieval theories of vision. Int J Hist Philos Med 5:10510

24. Iskandar A (1990) Al Razi. In: Religion, learning and science in the Abbasid Period. In: Young MJ, Latham DJ SR (ed) The Cambridge history of Arabic literature. Cambridge University Press, Cambridge, pp 370-377

25. Bryson J (2010) The Hawi by Razi (ca. 865-965 C.E.), Book one on nerve, brain, and mental disorders: Arabic sources for the history of neuroscience [Abstract]. In: Fifth Annual Meeting of the International Society for the History of the Neurosciences (ISHN). Rhode Island, p 243

26. Bateni G (2019) Annotated Persian translation of the continence of Rhazes. Rhazes, Birmingham

27. Watson-Williams E (1927) the significance of Vertigo. Bristol Med Chir J (1883) 44:119-124

28. Maltby MT (2012) Ancient voices on tinnitus: the pathology and treatment of tinnitus in Celsus and the Hippocratic Corpus compared and contrasted. Int Tinnitus J 17:140-145

29. Gaw AC (1906) The development of the legal status of the deaf: a comparative study of the rights and responsibilities of deaf-mutes in the laws of Rome, France, England, and America. Am Ann Deaf 51:401-423

30. Cawthorne T (1958) Julius Caesar and the falling sickness. Proc R Soc Med 51:27-30

31. Spencer W (1938) Celsus: De Medicina. With an English translation. William Heinemann, London

32. Pearce JMS (2013) The neurology of Aretaeus: Radix Pedis Neurologia. Eur Neurol 70:106-112

33. Stephens D, Mudry A (2012) Ménière's disorder: a short history. Audiol Med 10:153-159

34. Adams F (1834) Commentary on the third book of Paulus Ægineta. In: The medical works of Paulus Ægineta: translated into English, with a copious commentary, Vol 1. G. Cornwall, London, p 376

35. Wear A (1985) Explorations in renaissance writings on the practice of medicine. In: Wear A, French RK, Lonie IM (eds) The medical renaissance of the sixteenth century. Cambridge Universiety Press, Cambridge, pp 118-145

36. Puschmann T (1878) Alexander von Tralles : original-text und Übersetzung nebst einer einleitenden Abhandlung, Ein Beitrag zur Geschichte der Medicin, Vol 1. Wilhelm Braumüller, Vienna, pp 124, 534-536

37. Anonymous (1848) The seven books of Paulus Ægineta: translated from the Greek: with a commentary, embracing a complete view of the knowledge possessed by the Greeks, Romans, and Arabians, on all subjects connected with medicine and surgery. Br Foreign Medico-Chirurgical Rev 2:55-61

38. Lorch M (2006) Language and memory disorder in the case of Jonathan Swift: considerations on retrospective diagnosis. Brain 129:3127-3137

39. Martini S, Martini A, Garosi E, Mion M, Stephens D (2018) The symptoms of Ménière's disorder as described by Bonaventura Angeli in De Vertigine et Scotomia (1565). Hear Balanc Commun $16: 271-279$

40. Ménière $P$ (1861) Mémoire sur des lésions de l'oreille interne donnant lieu à des symptômes de congestion cérébrale apoplectiforme. 16:597-601

41. Pearce J (1994) A note on Menière's syndrome. J Neurol Neurosurg Psychiatry 57:858

42. Baloh RW (2001) Prosper Ménière and his disease. Arch Neurol 58: 1151-1156 
43. Gruber J (1895) Über Morbus Ménière. Monstsschr Ohrenheilk 29: 181-184

44. Pearce J (2003) Fragments of neurological history. Imperial College Press, London, pp 265-266

45. Flood LM, Kenyon G (2014) Concepts of Ménière's disease in the archives of the journal of laryngology and otology. J Laryngol Otol 128:1-10

46. Clark RJ (1938) Meniere's syndrome: differential diagnosis and treatment. N Engl J Med 219:388-391
47. Huppert D, Brandt T (2018) Dizziness and vertigo syndromes viewed with a historical eye. J Neurol 265:127-133

48. Bennett J, Young J (2001) Offbeat otolaryngology. Thieme, Stuttgart/New York, p 66

Publisher's note Springer Nature remains neutral with regard to jurisdictional claims in published maps and institutional affiliations. 